ISSN 1392-3196 / e-ISSN 2335-8947

Zemdirbyste-Agriculture, vol. 102, No. 1 (2015), p. 23-30

DOI $10.13080 / \mathrm{z}-\mathrm{a} .2015 .102 .003$

\title{
Properties of Luvisol and spring barley yield as affected by peas as a catch crop
}

\author{
Edward WILCZEWSKI, Anna PIOTROWSKA-DŁUGOSZ, Grzegorz LEMAŃCZYK \\ University of Technology and Life Sciences \\ Kordeckiego 20, 85-225 Bydgoszcz, Poland \\ E-mail: edward@utp.edu.pl
}

\begin{abstract}
The share of cereals in the total area of agricultural crops is currently too high, which leads to deterioration of soil properties and makes it difficult to obtain high yields. The objective of this research was to determine the effect of field pea grown as a catch crop on soil properties and yielding capacity of spring barley cultivated after the catch crop, in a cereal crop rotation. Three treatments of catch crop management were studied: A - catch crop ploughed in in the autumn, B - catch crop left as mulch for the winter, $\mathrm{C}$ - control (without a catch crop). Experiments were carried out on a Luvisol ( $L V$ ) in a randomized block design. The catch crop biomass ploughed in significantly improved moisture and reduced compaction of the topsoil before sowing spring barley. Use of field pea as a catch crop increased enzymatic activity and mineral nitrogen content in the soil before sowing and during tillering of barley. The effect of mulch was stronger than that obtained in the treatment with biomass ploughed in in the autumn. Catch crop significantly improved the yield of spring barley, which was mainly due to increasing the number of spikes and grains per spike in barley grown after the catch crop ploughed in, and due to increasing the number of grains per spike in the treatments with mulch. Physical and biological properties of soil in cereal crop rotations may be substantially improved by catch crop, especially used as mulch. Catch crop influence on spring barley yield was independent of its management method.
\end{abstract}

Key words: field pea, green manure, mulch, soil microbial biomass, spring barley.

\section{Introduction}

Due to the steadily increasing human population (United Nations, 2006) and the consequent increasing demand for plant products to satisfy the needs for food and energy, it is necessary to continue to increase plant productivity. Intensification of crop production by increasing the amount of chemicals used in production leads to the air and water pollution (Di, Cameron, 2002). Therefore it is recommended to use such methods of agricultural production intensification which are safe for the environment and allow a sustainable development of agriculture (Doltra, Olesen, 2013). One of such methods is growing catch crops and using the biomass produced by them as green manure. It is of particular importance on farms where the lack of animal production causes a shortage of farmyard manure. Growing a catch crop for green manure can bring many benefits for the soil environment, which has been indicated by the research carried out in this area (Berntsen et al., 2006; Piotrowska, Wilczewski, 2012; Riddle, Bergstrőm, 2013). Catch crops take up nitrogen remaining in the soil after harvest of cereals and thus enable reduction of its leaching (Duer, 1996; Vos, van-der-Putten, 2001; Berntsen et al., 2006; Askegaard, Eriksen, 2008; Doltra, Olesen, 2013). This reduces environmental risks, improves soil fertility and increases the supply of this component for successive plants. Consequently, it is possible to obtain both higher grain yields (Askegaard, Eriksen, 2008; Doltra, Olesen, 2013) and improvement in their quality by increasing the total protein content (Skinder, Wilczewski, 2004), as a result of growing catch crops. Used as green manure, they increase the content and activity of the soil microbial biomass and improve the soil enzymatic activity (Piotrowska, Wilczewski, 2012; Janušauskaitė et al., 2013).

Many studies have concerned the impact of catch crops grown as green manure on the physical and chemical properties of soil (Hansen, Djurhuus, 1997; Thorup-Kristensen, Dresbøll, 2010; Riddle, Bergstrőm, 2013). Findings presented in the literature relate primarily to the impact of catch crops on soil properties during the early spring (before sowing of spring cereals). Little is known, however, about the soil compaction, its mineral nitrogen $\left(\mathrm{N}_{\min }\right)$ content and enzymatic activity during different growth stages of cereals.

The aim of this study was to determine the effect of field pea (Pisum sativum L.) grown as a catch crop intended for green manure on some physical, chemical and biological properties of the soil during different growth stages of spring barley (Hordeum vulgare L.) and yield of this plant grown in cereal crop rotation conditions.

\section{Materials and methods}

Experimental design and conditions. Field experiments were conducted at the Research Station in Mochełek near Bydgoszcz in Midwest Poland (17 $51^{\prime}$ $\mathrm{E}, 53^{\circ} 13^{\prime} \mathrm{N}$ ) in a randomized block design, with four 
replications. The plot area was $250 \mathrm{~m}^{2}$ for sowing and $140 \mathrm{~m}^{2}$ for harvesting of spring barley. The experimental factor was the method and time of catch crop management: A - catch crop ploughed in in autumn, B - catch crop left uncut as mulch for winter, $\mathrm{C}-$ control (without a catch crop). Field experiments were performed in 2008-2011. In 2008, 2009 and 2010, field pea was cultivated as a catch crop and used as green manure for spring barley sown the following year. According to the IUSS Working Group WRB (2007), the soil used in the experiment was a Luvisol ( $L V)$ with a fine sandy loam texture. The soil was characterized by a very high content of available phosphorus and potassium (103 and $234 \mathrm{mg}$ of $\mathrm{P}$ and $\mathrm{K}$ in $\mathrm{kg}$ of dry soil, respectively), high magnesium concentration (72 mg of $\mathrm{Mg}$ in $\mathrm{kg}$ of dry soil) and slightly acidic reaction ( $\mathrm{pH}$ in $1 \mathrm{M} \mathrm{KCl} \mathrm{6.1).} \mathrm{The} \mathrm{concentration} \mathrm{of}$ total nitrogen and organic carbon in the soil amounted to $0.078 \%$ and $0.877 \%$, respectively.

The total precipitation during the field pea growing period varied between years (Table 1). In 2008 and 2010, very high rainfalls were noted in August. They provided a good water supply for germinating pea seeds. In 2009, we observed a significant lack of rainfall in August and September. Proper growth of pea in that year was made possible by the high total precipitation in July.

Table 1. Weather conditions at the experiment site

\begin{tabular}{cccccc}
\hline Month & 2008 & 2009 & 2010 & 2011 & $1949-2010$ \\
\hline \multicolumn{5}{c}{ Total } & precipitation mm \\
March & 61.2 & 43.7 & 28.6 & 11.7 & 24.7 \\
April & 38.7 & 0.4 & 33.8 & 13.5 & 27.7 \\
May & 11.5 & 85.3 & 92.6 & 38.4 & 43.2 \\
June & 15.5 & 57.4 & 18.1 & 100.8 & 52.9 \\
July & 58.7 & 118.0 & 107.4 & 132.5 & 72.2 \\
August & 95.5 & 17.6 & 150.7 & 67.7 & 53.0 \\
September & 20.2 & 34.4 & 74.7 & 37.0 & 41.4 \\
October & 80.0 & 66.2 & 2.3 & 13.2 & 32.8 \\
\hline Total & 381.3 & 423.0 & 508.2 & 414.8 & 347.9 \\
March-October & \multicolumn{5}{c}{} \\
\hline \multicolumn{5}{c}{ Average air temperature ${ }^{\circ} \mathrm{C}$} \\
March & 3.0 & 2.4 & 2.4 & 2.2 & 1.9 \\
April & 7.6 & 9.8 & 7.8 & 10.5 & 7.4 \\
May & 13.2 & 12.3 & 11.5 & 13.5 & 12.7 \\
June & 17.6 & 14.5 & 16.7 & 17.7 & 16.2 \\
July & 19.2 & 18.6 & 21.6 & 17.5 & 18.0 \\
August & 17.8 & 18.2 & 18.4 & 17.7 & 17.5 \\
September & 12.4 & 13.7 & 12.2 & 14.3 & 13.2 \\
October & 8.4 & 6.3 & 5.5 & 8.4 & 8.1 \\
\hline Mean & 12.4 & 12.0 & 12.0 & 12.7 & 11.9 \\
March-October & & & & & \\
\hline & & & &
\end{tabular}

During the spring barley growing season, the precipitation totals were relatively high throughout the research period. However, in none of the three years of research it was consistent with the needs of barley. In 2009, a fairly good supply of barley with rain water was observed from the beginning of stem elongation to maturity. In 2010, there was a shortage of precipitation before and during grain formation (June). In 2011, a deficit of rainfall occurred during the tillering and stem elongation stages (April-May). Air temperature during the main period of the catch crop growth was similar in all years of the study. Relatively high temperatures were observed in July and August. They were higher than the means of 1949-2010 for this area. Relatively high temperatures in the first half of October 2008 had a positive impact on the growth and yield of the catch crop. The thermal conditions were favourable for barley. Air temperatures in April in all the research years were higher than the long-term mean for the region. This enabled the dynamic growth of plants during emergence. In 2010, air temperatures were relatively low in May and high in June.

Crop management. The seeds of field pea were sown within 5-9 August, in the stand of winter wheat. Catch crop was harvested using a rail mounted mower within the period from 15 October to 3 November. Ploughing to a depth of about $27 \mathrm{~cm}$ was made after harvesting of catch crop, in treatments A and C. Fertilisation of spring barley with phosphorus and potassium was done in the spring at rates $26.2 \mathrm{~kg} \mathrm{ha}^{-1} \mathrm{P}$ and $66.4 \mathrm{~kg} \mathrm{ha}^{-1} \mathrm{~K}$. Nitrogen was applied at the dose of $90 \mathrm{~kg} \mathrm{ha}^{-1} \mathrm{~N}$ divided into two parts. The first part of the dose $\left(45 \mathrm{~kg} \mathrm{ha}^{-1} \mathrm{~N}\right)$ was applied prior to sowing and the second $\left(45 \mathrm{~kg} \mathrm{ha}^{-1} \mathrm{~N}\right)$ during the shooting stage. The soil in treatments $\mathrm{A}$ and $\mathrm{C}$ was cultivated using a cultivator with a crumbler roller. Mulch of field pea (treatment B) was cut and mixed with the soil using a disk harrow, to a depth of $10 \mathrm{~cm}$ in March 2009, 2010 and 2011. Spring barley was sown between 2-4 April, using a row drill in treatment $\mathrm{A}$ and $\mathrm{C}$ and a drill equipped with coulters in treatment B.

Field and laboratory studies of catch crop. After sowing catch crop, observation of the plant development was conducted. After emergence, plant density (plants $\mathrm{m}^{-2}$ ) was calculated. In the second half of October the fresh matter yield of plants in treatment A was weighed. Dry matter yield was determined based on samples of fresh matter (about $1 \mathrm{~kg}$ ) taken from each plot. Samples were weighed, dried in an oven at $50^{\circ} \mathrm{C}$, and then re-weighed. In treatment $\mathrm{A}$, mowed fresh matter, after weighing and fragmentation, was ploughed in to a depth of the topsoil, and in treatment B it was left uncut until spring. The yield of post-harvest residues was determined in samples taken from soil monoliths 25 $\times 25 \times 25 \mathrm{~cm}$. Four samples were randomly collected from each plot and after the initial screening they were sieved and rinsed in running water. After drying on absorbent paper, the samples were weighed, dried in an oven at $50^{\circ} \mathrm{C}$ and re-weighed to determine the dry matter yield. In the samples of the aboveground biomass and post-harvest residues, the concentrations of nitrogen (using Kjeldahl method), phosphorus (using vanadiummolybdenum method), potassium and calcium (by flame photometry method) and magnesium (colorimetrically with titan yellow) were assayed.

Field and laboratory studies of spring barley. Before spring barley sowing, as well as during tillering and stem elongation, penetration resistance measurements were made in layers: $0-5,5-10,10-15$, $15-20,20-25$ and $25-30 \mathrm{~cm}$, using a hand penetrometer. Soil samples were taken from three layers $(5-15,25-$ 35 and $45-55 \mathrm{~cm}$ ) to determine the moisture (using drying-weighing method). Moreover, at the same times soil samples from the topsoil were taken to determine the content of mineral nitrogen $\left(\mathrm{N}_{\text {min }}\right)$. Colorimetric analysis was carried out in the laboratory of the Regional 
Chemical-Agricultural Station, using apparatus $\mathrm{SAN}^{++}$ system (Skalar Analytical B.V., the Netherlands). After the spring barley emergence, plant density (plants $\mathrm{m}^{-2}$ ) was determined. The number of spikes was measured in samples taken from $1 \mathrm{~m}^{2}$ area in each plot before harvest of barley. From each sample 20 spikes were randomly taken, based on which the number of grains per spike was determined. Biological activity of the soil measured by the determination of dehydrogenase (DH) and fluorescein sodium salt hydrolysis (FDAH) activities was evaluated four times a year during the experimental period. DH activity was determined according to the method described by Thalmann (1968). One unit of DH was defined as the amount of TPF (triphenyl formazan) in $\mathrm{mg}$ released at $30^{\circ} \mathrm{C} \mathrm{h}^{-1}$ by $1 \mathrm{~kg}$ of dried soil. The global soil hydrolysis activity was evaluated by measuring the activity of FDAH (Adam, Duncan, 2001). One unit of FDAH activity was expressed as $\mathrm{mg}$ of fluorescein produced at $37^{\circ} \mathrm{C}$ by $1 \mathrm{~kg}$ of dried soil.

Statistical analysis. A mixed model of analyses of variance was used to verify the effect of method and time of catch crop management on the studied features. When significant effects of the studied factor were found, Tukey's test at the significance level $P \leq 0.05$ was used to compare treatment means. The correlation coefficients were calculated using Statistica for Windows.

\section{Results}

The yield of catch crop, its chemical composition and influence on soil properties. Dry matter yield of the catch crop varied between years (Table 2). It was the highest in 2008 and the lowest in 2009.

Table 2. Dry matter yield of field pea grown as a catch crop $\left(\mathrm{Mg} \mathrm{ha}^{-1}\right)$

\begin{tabular}{cccc}
\hline \multirow{2}{*}{ Type of biomass } & \multicolumn{3}{c}{ Year } \\
\cline { 2 - 4 } & 2008 & 2009 & 2010 \\
\hline Green matter & $3.1\left(0.23^{*}\right)$ & $1.7(0.13)$ & $2.0(0.19)$ \\
Post-harvest residue & $1.1(0.28)$ & $0.7(0.18)$ & $0.8(0.20)$ \\
\hline Total biomass & $4.2(0.37)$ & $2.4(0.22)$ & $2.8(0.04)$ \\
\hline
\end{tabular}

* - standard deviation

Green matter of field pea was richer in nitrogen, phosphorus, potassium and magnesium than post-harvest residues, which contained about 20.4\% more calcium than the green matter (Table 3). On average $101 \mathrm{~kg} \mathrm{ha}^{-1}$ $\mathrm{K}, 89 \mathrm{~kg} \mathrm{ha}^{-1} \mathrm{~N}$ and $12 \mathrm{~kg} \mathrm{ha}^{-1} \mathrm{P}$ was accumulated in the catch crop biomass.

Table 3. Concentration of macronutrients in catch crops biomass ( $\%$ of dry weight), means 2008-2010

\begin{tabular}{|c|c|c|c|c|c|}
\hline \multirow{2}{*}{ Type of biomass } & \multicolumn{5}{|c|}{ Macronutrient } \\
\hline & $\mathrm{N}$ & $P$ & $\mathrm{~K}$ & $\mathrm{Ca}$ & $\mathrm{Mg}$ \\
\hline Green matter & $3.12(0.37 *)$ & $0.406(0.05)$ & $3.46(0.29)$ & $0.82(0.24)$ & $0.205(0.02)$ \\
\hline Post-harvest residue & $2.30(0.36)$ & $0.330(0.10)$ & $2.75(0.60)$ & $1.03(0.25)$ & $0.169(0.02)$ \\
\hline
\end{tabular}

* - standard deviation

Field pea grown as a catch crop for green manure positively affected the concentration of $\mathrm{N}_{\min }$ in the arable layer of soil (Fig. 1). The content of $\mathrm{N}_{\min }$ in the soil in March was the highest in the treatment with mulch of catch crop. Moreover, significantly more $\mathrm{N}_{\min }$ was found in the soil where catch crop had been ploughed in than in the control. In May and August, the soil with mulch was more abundant in this nutrient than that in the other treatments. In June, the content of $\mathrm{N}_{\min }$ in both catch crop treatments was higher than in the control.

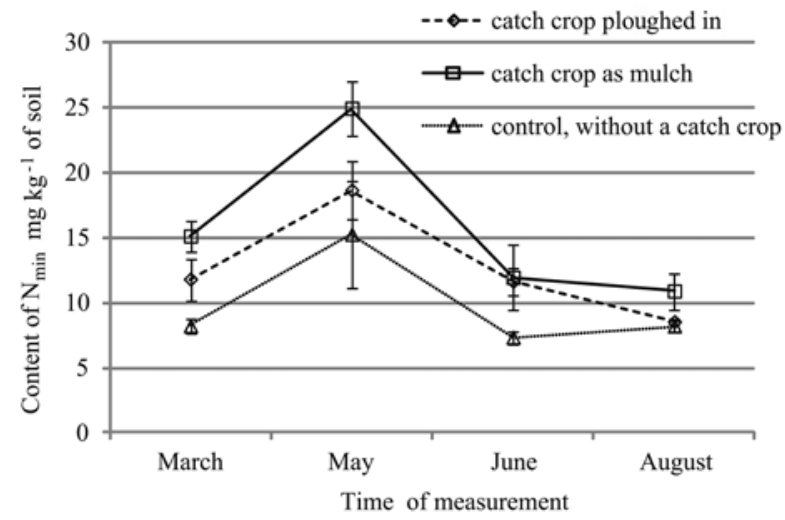

Note. Bars show standard deviations.

Figure 1. Content of mineral nitrogen $\left(\mathrm{N}_{\min }\right)$ in the topsoil $(0-30 \mathrm{~cm})$ in the period of spring barley cultivation, means from 2009-2011
The DH and FDAH activities are presented as a function of the method and time of catch crop management (Table 4). The highest DH activity was found in the mulched plots for all sampling dates, except the shooting stage of spring barley. Lower values of DH activity were determined in treatment $\mathrm{A}$ followed by the control plots (C). In the whole studied period, the lowest DH activity was noted before spring barley sowing. The highest DH activity was noted after the harvest of spring barley. The highest FDAH activity was found in soil samples taken during spring barley tillering and the lowest after its harvest. Before spring barley sowing as well as during its tillering and shooting, FDAH activity was the highest in the treatment with mulch of the catch crop. After harvest of spring barley, higher FDAH activity occurred in both methods of catch crop management than in the control.

Soil moisture was the highest before spring barley sowing (Table 5). The moisture in the topsoil (5$15 \mathrm{~cm}$ ) was generally higher than in the deeper layers. Only during tillering the water content was similar in all studied layers. The catch crop adversely affected humidity of the topsoil $(5-15 \mathrm{~cm})$, measured immediately after harvesting the plants. Before the sowing of barley, the soil covered with catch crop mulch contained significantly more water in the $5-15 \mathrm{~cm}$ layer than that with the pea biomass ploughed in in the autumn. The moisture of this layer was the weakest in the control, without the catch crop. During the tillering of barley, moisture was the highest in the soil without catch crop and significantly less water was in the treatment with the catch crop 
Table 4. Dehydrogenase (DH) and fluorescein sodium salt hydrolysis (FDAH) activity in the topsoil as affected by catch crop management, means from 2009-2011

\begin{tabular}{ccc}
\hline \multirow{2}{*}{ Treatment } & \multicolumn{2}{c}{ Enzyme } \\
\cline { 2 - 3 } & DH $\left(\mathrm{mg} \mathrm{kg}^{-1} \mathrm{~h}^{-1} \mathrm{TPF}\right)$ & FDAH $\left(\mathrm{mg} \mathrm{kg}^{-1} \mathrm{~h}^{-1} \mathrm{~F}\right)$ \\
\hline & \multicolumn{2}{c}{ Before sowing of spring barley } \\
$\mathrm{B}$ & $2.37 \mathrm{~b}$ & $54.51 \mathrm{~b}$ \\
$\mathrm{C}$ & $3.16 \mathrm{a}$ & $57.07 \mathrm{a}$ \\
\hline Mean & $1.65 \mathrm{c}$ & $43.91 \mathrm{c}$ \\
\hline & 2.39 & 51.84 \\
$\mathrm{~A}$ & During tillering of spring barley \\
$\mathrm{B}$ & $3.60 \mathrm{~b}$ & $56.11 \mathrm{~b}$ \\
$\mathrm{C}$ & $4.59 \mathrm{a}$ & $61.52 \mathrm{a}$ \\
\hline Mean & $2.71 \mathrm{c}$ & $55.04 \mathrm{~b}$ \\
\hline & 3.63 & 57.56 \\
$\mathrm{~A}$ & During shooting of spring barley \\
$\mathrm{B}$ & $3.56 \mathrm{a}$ & $45.52 \mathrm{~b}$ \\
$\mathrm{C}$ & $3.57 \mathrm{a}$ & $50.40 \mathrm{a}$ \\
\hline Mean & $2.86 \mathrm{~b}$ & $41.13 \mathrm{c}$ \\
\hline & 3.33 & 45.68 \\
A & After harvest of spring barley \\
B & $5.86 \mathrm{~b}$ & $40.61 \mathrm{a}$ \\
$\mathrm{C}$ & $8.56 \mathrm{a}$ & $41.05 \mathrm{a}$ \\
\hline Mean & $6.04 \mathrm{~b}$ & $38.11 \mathrm{~b}$ \\
\hline A & 6.82 & 39.92 \\
\hline
\end{tabular}

Notes. A - catch crop ploughed in in the autumn, B - catch crop as mulch, $\mathrm{C}$ - control, without a catch crop; TPF - triphenyl formazan, $\mathrm{F}$ - fluorescein. Means marked with the same letter within particular columns are not significantly different at $P \leq 0.05$.

biomass ploughed in. This was observed regardless of the measurement depth. At the shooting stage there was no significant effect of catch crops on the water content in the topsoil. The deeper layers were the most moist when the catch crop was used as mulch, and significantly drier with the catch crop ploughed in.

Penetration resistance of soil in October was significantly higher in the treatments with catch crops than in the control in all studied layers (Fig. 2). Prior to the spring barley sowing, the highest penetration resistance was in the treatment where the catch crop was left for winter in the form of mulch. In the soil with the catch crop ploughed in, penetration resistance in early spring in the $0-5 \mathrm{~cm}$ layer was lower than in the control without a catch crop. Penetration resistance at the barley tillering stage (May) was significantly higher in the soil with the
Table 5. Soil moisture (\% of weight), means from 2009 2011

\begin{tabular}{cccc}
\hline \multirow{2}{*}{ Treatment } & \multicolumn{3}{c}{ Layer of soil cm } \\
\cline { 2 - 4 } & $5-15$ & $25-35$ & $45-55$ \\
\hline A & In the autumn, after harvesting of catch crop* \\
C & $7.76 \mathrm{~b}$ & 6.47 & 6.59 \\
Mean & $8.22 \mathrm{a}$ & 6.69 & 6.57 \\
\hline \multicolumn{4}{c}{ Before sowing of spring barley } \\
A & $12.4 \mathrm{~b}$ & 10.7 \\
$\mathrm{~B}$ & $13.1 \mathrm{a}$ & 10.7 & 6.58 \\
$\mathrm{C}$ & $11.8 \mathrm{c}$ & 10.6 & 10.0 \\
Mean & 12.4 & 10.7 & 9.7 \\
\hline \multicolumn{4}{c}{ During tillering of spring barley } \\
$\mathrm{A}$ & $7.14 \mathrm{~b}$ & $7.03 \mathrm{~b}$ \\
$\mathrm{~B}$ & $7.27 \mathrm{ab}$ & $7.14 \mathrm{ab}$ & $7.13 \mathrm{~b}$ \\
$\mathrm{C}$ & $7.54 \mathrm{a}$ & $7.35 \mathrm{a}$ & $7.16 \mathrm{~b}$ \\
\hline Mean & 7.32 & 7.17 & $7.63 \mathrm{a}$ \\
\hline \multicolumn{4}{c}{ During shooting of spring barley } \\
$\mathrm{A}$ & 7.10 & $6.08 \mathrm{~b}$ & $6.17 \mathrm{~b}$ \\
$\mathrm{~B}$ & 7.49 & $6.26 \mathrm{a}$ & $6.58 \mathrm{a}$ \\
$\mathrm{C}$ & 7.51 & $6.20 \mathrm{ab}$ & $6.46 \mathrm{ab}$ \\
\hline Mean & 7.37 & 6.18 & 6.40 \\
\hline
\end{tabular}

Notes. A - catch crop ploughed in in the autumn, B - catch crop as mulch, $\mathrm{C}-$ control, without a catch crop; * - means from 2008-2010. Means marked with the same letter within particular columns are not significantly different at $P \leq 0.05$.

catch crop mulch than in the other treatments. The soil without a catch crop was characterized by the smallest penetration resistance in most layers of the topsoil. In the 5 to $20 \mathrm{~cm}$ and 25 to $30 \mathrm{~cm}$ layers in the treatments with the catch crop ploughed in, soil compaction was significantly higher than in the control. The soil penetration resistance at the shooting stage of barley (June) was also the highest in the treatment without ploughing and with the catch crop left as mulch.

The yield of spring barley and its structure. Grain and straw yield of spring barley varied greatly between the years of the study (Table 6). In two out of three research years, the catch crop helped to increase the grain yield. Significant impact of the catch crop on the straw yield was showed only in 2011.

The average results of three years of research showed a significant positive impact of the catch crop on the yield of barley grain and straw. Spring barley yield was positively correlated with the number of spikes

Table 6. Yield of spring barley

\begin{tabular}{ccccc}
\hline \multirow{2}{*}{ Treatment } & \multicolumn{5}{c}{ Year } \\
\cline { 2 - 5 } & 2009 & 2010 & 2011 & Mean 2009-2011 \\
\hline & & Grain yield $\mathrm{Mg} \mathrm{ha}^{-1}$ & \\
$\mathrm{~A}$ & $7.10\left(0.16^{*}\right) \mathrm{a}$ & $4.12(0.14)$ & $3.93(0.12) \mathrm{ab}$ & $5.05(1.52) \mathrm{a}$ \\
$\mathrm{B}$ & $7.20(0.20) \mathrm{a}$ & $4.02(0.22)$ & $4.23(0.18) \mathrm{a}$ & $5.15(1.53) \mathrm{a}$ \\
$\mathrm{C}$ & $6.54(0.36) \mathrm{b}$ & $4.10(0.03)$ & $3.62(0.15) \mathrm{b}$ & $4.75(1.35) \mathrm{b}$ \\
\hline Mean & 6.95 & 4.08 & 3.92 & 4.98 \\
\hline A & $3.71(0.32)$ & Straw yield Mg ha ${ }^{-1}$ & & $2.81(0.73) \mathrm{a}$ \\
B & $3.59(0.24)$ & $2.12(0.24)$ & $2.60(0.16) \mathrm{a}$ & $2.88(0.60) \mathrm{a}$ \\
C & $3.42(0.16)$ & $2.24(0.16)$ & $2.80(0.21) \mathrm{a}$ & $2.37(0.80) \mathrm{b}$ \\
\hline Mean & 3.57 & $1.78(0.13)$ & $2.88(0.16) \mathrm{b}$ & 2.69
\end{tabular}

Notes. A - catch crop ploughed in in the autumn, B - catch crop as mulch, C - control, without a catch crop; * - standard deviation. Means marked with the same letter within particular columns are not significantly different at $P \leq 0.05$. 

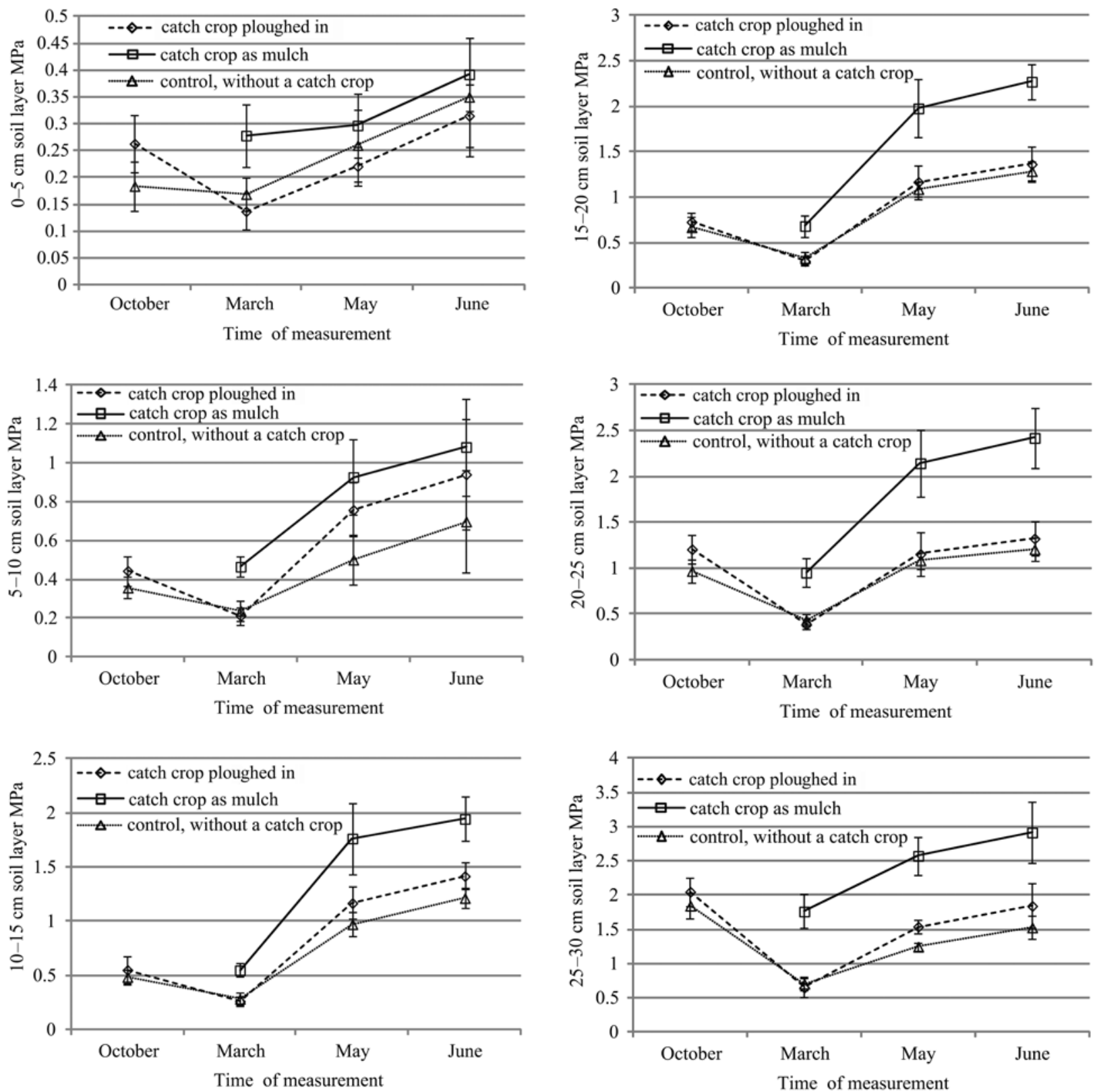

Note. Bars show standard deviations.

Figure 2. Penetration resistance of the topsoil, after catch crops harvest (October) and in the spring, before spring barley sowing (March) and during its growth (May and June), means from 2009-2011

(Table 7). There was no evidence of correlation between the number of grains per spike and 1000 grain weight $v s$ the yield of grain and straw. The relationship between the yield and the length of stalks and spikes was not evident either.

The number of plants after emergence was not related to the experimental treatments (Table 8). Differentiation of barley grain yield resulted from a significant increase in the number of spikes and grains per spike in the treatment with the catch crop ploughed in. Barley grown after the catch crop, which was used as mulch, developed a significantly higher number of grains per spike than in the control. Weight of 1000 grains of barley grown with the catch crop ploughed in was significantly lower than that after the mulch and in the control.

Table 7. Simple correlation coefficients for the relationship between grain and straw yield of spring barley and yield components 2009-2011 ( $=9)$

\begin{tabular}{cccccc}
\hline Variable & Number of spikes & $\begin{array}{c}\text { Number of grains } \\
\text { per spike }\end{array}$ & 1000 grain weight & Stalk length & Spike length \\
\hline Grain yield & $0.99^{* *}$ & 0.22 & 0.49 & 0.41 & 0.23 \\
Straw yield & $0.91^{* *}$ & -0.02 & 0.60 & 0.17 & 0.04 \\
\hline
\end{tabular}


Table 8. Yield components of spring barley, means from 2009-2011

\begin{tabular}{ccccc}
\hline Treatment & $\begin{array}{c}\text { Number of plants after emergence } \\
\mathrm{m}^{-2}\end{array}$ & $\begin{array}{c}\text { Number of spikes } \\
\mathrm{m}^{-2}\end{array}$ & $\begin{array}{c}\text { Number of grains } \\
\text { per spike }\end{array}$ & $\begin{array}{c}1000 \text { grain weight } \\
\mathrm{g}\end{array}$ \\
\hline $\mathrm{A}$ & $318\left(27.9^{*}\right)$ & $731(169) \mathrm{a}$ & $20.8(3.06) \mathrm{a}$ & $40.8(4.24) \mathrm{b}$ \\
$\mathrm{B}$ & $310(22.8)$ & $704(195) \mathrm{b}$ & $21.2(2.53) \mathrm{a}$ & $41.8(4.21) \mathrm{a}$ \\
$\mathrm{C}$ & $322(34.3)$ & $692(193) \mathrm{b}$ & $19.6(3.33) \mathrm{b}$ & $41.8(3.87) \mathrm{a}$ \\
\hline Mean & 317 & 709 & 20.5 & 41.5 \\
\hline
\end{tabular}

Notes. A - catch crop ploughed in in the autumn, B - catch crop as mulch, C - control, without a catch crop; *-standard deviation. Means marked with the same letter within particular columns are not significantly different at $P \leq 0.05$.

\section{Discussion}

Yield of a catch crop and its influence on the content of $N_{\text {in }}$ in the topsoil. The crop biomass of field pea obtained in the present study can be considered as typical of legumes grown as a catch crop. It was the highest in 2008 , the year characterized by a good supply of water throughout the period of field pea growth. In 2009 , green matter yield was about $45 \%$ lower because of the shortage of rainfall in August and September. However, good soil humidity in July enabled obtaining the sufficient plant density. According to our previous study (Wilczewski et al., 2012), the water resources in the soil from rainfall in July allow for a normal growth of plants even under shortage of rainfall over the period from August to October.

Increased content of $\mathrm{N}_{\min }$ in the soil where catch crop was used as mulch could be due to delayed mineralization of field pea biomass in this treatment. In general, the plants were damaged by low temperatures in December. Thus before the winter, mineralization in this treatment was limited because of the field pea growth. In the winter it was limited by low temperatures. Thus mineralization in the treatment with catch crop used as mulch took place mainly in the spring. This is indicated by higher values of microbiological parameters during tillering and stem elongation of barley. The activity of the studied enzymes during tillering of barley was higher (about $27.5 \%$ for DH activity and $9.6 \%$ for FDAH activity) in the treatment with mulch than in the treatment with the catch crop ploughed in. The results are consistent with the findings by Duer (1996), who stated a significantly faster decomposition of the catch crop biomass ploughed in, compared to that left as mulch. Thorup-Kristensen and Dresbøll (2010) showed that in years with large precipitation totals in winter, catch crop biomass incorporation in spring provides a higher availability of $\mathrm{N}_{\min }$ in the soil to plants in May compared with autumn incorporation. According to the authors, the introduction of the catch crop biomass into the soil in early autumn can result in rapid mineralization and leaching of nitrogen from the soil before sowing of succeeding crops. The total precipitation during the winter in two of three years of our research was higher than the long-term average. Hence the topsoil in treatment with ploughed in biomass was less abundant in $\mathrm{N}_{\min }$ in the period before sowing of barley (in March) and during tillering (in May), compared with the treatment with mulch.

Soil microbial biomass activity. The results of our study showed that the microbial biomass expressed as DH and FDAH activities was greater in the plots with catch crop, compared with the control. Stimulation of soil FDAH activity under catch crop management, especially leguminous cover crops, had been previously documented
(Reddy et al., 2003). As stated by Zablotowicz et al. (2011) in the first year of sampling, FDAH activity in non-cover crop soils was $25 \%$ to $30 \%$ higher, compared with soil from plots managed with cover crops. However, after the third year of successive cover crop management, FDAH activity was significantly higher in the plots with Austrian winter pea and hairy vetch than in non-covered area. DH activity appeared to be more seasonally variable than was the FDAH activity. Generally, DH are the group of the most variable enzymes determined in soil and their activity is very sensitive both to natural and anthropogenic factors (Samuel, 2010). Lower variations in FDAH activity were expected since the activity is, after all, a measure of the overall hydrolytic ability of a soil and it reflects the positive and negative contributions due to the different hydrolytic enzyme activities, such as proteases, esterases and lipases (Gianfreda et al., 2005; Piotrowska et al., 2006). The seasonal changes in enzymatic activity can be explained by the enhanced rhizosphere microbial population that accompanies the rapid development of the crop root systems during the growing period (Richardson et al., 2009). Mulched plots had a greater stimulatory effect on soil biological parameters, compared with field pea ploughed in in the autumn (Table 4), which was due to improvement of soil moisture (Table 5) and $\mathrm{N}_{\min }$ content (Fig. 1). The increase in nitrogen content, when field pea was retained as mulch, could increase soil micro-organism population and consequently DH and FDAH activities.

Some physical properties of the soil. The results obtained in the present study indicate that the catch crop affects the physical properties of the soil both during the autumn and in the spring. The growth of plants contributed to the short-term reduction of the topsoil moisture in the autumn (about 5.6\%) and to the increase in penetration resistance (about 16.2\%). However, those unfavourable changes of soil physical properties did not increase fuel consumption during ploughing (data not presented). Despite the soil moisture reduction during the autumn, catch crop contributed to the improvement of the topsoil moisture before sowing of spring barley. This increase amounted to $5.1 \%$ in the treatment with the catch crop ploughed in, and $11.0 \%$ in the treatment with mulch. This effect on soil moisture was especially strong when the catch crop was left on the soil surface as mulch. The positive impact on soil moisture during early spring confirms the results concerning this subject presented in the literature (Duer, 1996). The soil in the control, without a catch crop, was generally more moist during barley tillering than that on which catch crop was grown. The reason for this variation may be increased water consumption in the treatment with ploughed in biomass of the catch crop, resulting from stronger tillering of barley. This is indicated by a significantly 
higher number of spikes in the catch crop treatment, compared with the control.

The adverse effect of catch crop on soil penetration resistance may be due to the lower humidity discussed earlier, which determines the strength of binding soil particles. Penetration resistance value increases along with reducing soil moisture (Vaz et al., 2011). Studies on the effect of soil compaction on plant growth indicate that the penetration resistance lower than $2 \mathrm{MPa}$ does not limit the development of roots (Hamza, Anderson, 2005; Lipiec et al., 2012). In our study, soil compaction during the growth of barley was less than $2 \mathrm{MPa}$ in the treatments where ploughing was performed. In the treatment without ploughing, where catch crop was left through the winter as mulch, penetration resistance exceeded 2.5 $\mathrm{MPa}$ during tillering of barley. It was mainly because of lack of ploughing. Further increase in soil compaction occurred at the shooting stage. Thus soil was too compact in the period of intensive growth of plants. However, it did not negatively affect the yield of barley. On the contrary, grain yield in that treatment was significantly higher than in the control, in the conditions of less compact soil. This may be due to a better supply of barley with nutrients, especially $\mathrm{N}_{\min }$ (Fig. 1).

Yield of spring barley. The impact of a catch crop on the soil conditions in the autumn and during the spring barley growth was ambiguous. However, the effect of a catch crop on the yield of spring barley was definitely positive. This may be due to an improvement in such soil properties which most strongly influence the growth of plants. An increased content of $\mathrm{N}_{\text {min }}$ was noted during barley emergence and tillering. It was particularly high in the soil where the catch crop was left for the winter as mulch (11.1-24.9 mg kg-1 $\mathrm{N}_{\min }$ of soil). Moreover, a positive effect on the initial growth of this plant could have resulted from higher soil moisture in the treatments with the catch crop and lower penetration resistance in the layer of $15-25 \mathrm{~cm}$ in the treatment with ploughed in biomass in this period. The positive impact of this factor on the growth of barley is shown by a significantly higher number of spikes in barley grown after the catch crop ploughed in than in the control. The method and time of mixing the catch crop with the soil did not affect the number of plants. However, the delay in emergence in the treatment with mulch resulted in reduced tillering of barley and producing less spikes, as compared with the treatment with ploughed in biomass of field pea. Nonetheless, the yield of barley grown with catch crop mulch was as high as in the treatment with ploughed in biomass. This was possible thanks to an increase in 1000 grain weight. Biomass mixed with the soil in early spring decomposed throughout the growth of barley and allowed elements released to improve the plant properties formed at the end of the growing season.

\section{Conclusions}

1. The catch crop contributed to the improvement of soil properties in the early spring as well as during the growth of spring barley and as a result, it significantly increased grain and straw yield. Particularly noteworthy is the increase in soil moisture and the content of mineral nitrogen $\left(\mathrm{N}_{\text {min }}\right)$ in the arable layer of soil covered with mulch over winter measured in the early spring. The improvement of soil properties contributed to the increase in grain yield by $6.3-8.4 \%$ as compared with the control.
2. The catch crop significantly increased soil microbiological activity measured as fluorescein sodium salt hydrolysis (FDAH) and dehydrogenase (DH) activities, as compared with the control. Generally, mulched field pea had a greater stimulatory effect on soil biological properties compared with the same catch crop ploughed in in the autumn.

3. The negative aspects of the catch crop may include short-term reduction in humidity and increased compaction of the topsoil during autumn.

\section{Acknowledgements}

Our scientific study was financed from the funds for science by Ministry of Science and Higher Education, in the years 2008-2011, as research project No. N N310 144135 .

Received 26032014

Accepted 29102014

\section{References}

Adam G., Duncan H. 2001. Development of a sensitive and rapid method for the measurement of total microbial activity using fluorescein diacetate (FDA) in a range of soils. Soil Biology and Biochemistry, 33 (7-8): 943-951 http://dx.doi.org/10.1016/S0038-0717(00)00244-3

Askegaard M., Eriksen J. 2008. Residual effect and leaching of $\mathrm{N}$ and $\mathrm{K}$ in cropping systems with clover and ryegrass catch crops on coarse sand. Agriculture, Ecosystems and Environment, 123 (1-3): 99-108 http://dx.doi.org/10.1016/j.agee.2007.05.008

Berntsen J., Olsen J. E., Petersen B. M., Hansen E. M. 2006. Long-term fate of nitrogen uptake in catch crops. European Journal of Agronomy, 25 (4): 383-390 http://dx.doi.org/10.1016/j.eja.2006.07.006

Di H. J., Cameron K. C. 2002. Nitrate leaching in temperate agroecosystems: sources, factors and mitigating strategies. Nutrient Cycling in Agroecosystems, 46: 237-256 http://dx.doi.org/10.1023/A:1021471531188

Doltra J., Olesen J. E. 2013. The role of catch crops in the ecological intensification of spring cereals in organic farming under Nordic climate. European Journal of Agronomy, 44: 98-108 http://dx.doi.org/10.1016/j.eja.2012.03.006

Duer I. 1996. Mulching effect of catch crop on barley yield, soil water and nitrogen storage. Fragmenta Agronomica, 13 (1): 29-43 (in Polish)

Gianfreda L., Rao M. A., Piotrowska A., Colombo C., Palumbo G. 2005. Influence of natural and anthropogenic factors on enzyme activity in soil. The Science of the Total Environment, 341: 265-279

http://dx.doi.org/10.1016/j.scitotenv.2004.10.005

Hamza M. A., Anderson W. K. 2005. Soil compaction in cropping systems. A review of the nature, causes and possible solutions. Soil and Tillage Research, 82: 121-145 http://dx.doi.org/10.1016/j.still.2004.08.009

Hansen E. M., Djurhuus J. 1997. Nitrate leaching as influenced by soil tillage and catch crop. Soil and Tillage Research, $41(3-4): 203-219$ http://dx.doi.org/10.1016/S0167-1987(96)01097-5

IUSS Working Group WRB. 2007. World Reference Base for Soil Resources 2006, first update 2007. World Soil Resources Reports No. 103. FAO, Rome

Janušauskaitė D., Arlauskienè A., Maikštenienè S. 2013. Soil mineral nitrogen and microbial parameters as influenced by catch crops and straw management. ZemdirbysteAgriculture, 100 (1): 9-18 http://dx.doi.org/10.13080/z-a.2013.100.002 
Lipiec J., Horn R., Pietrusiewicz J., Siczek A. 2012. Effects of soil compaction on root elongation and anatomy of different cereal plant species. Soil and Tillage Research, 121: $74-81$ http://dx.doi.org/10.1016/j.still.2012.01.013

Piotrowska A., Wilczewski E. 2012. Effects of catch crops cultivated for green manure and mineral nitrogen fertilization on soil enzyme activities and chemical properties. Geoderma, 189-190: 72-80 http://dx.doi.org/10.1016/j.geoderma.2012.04.018

Piotrowska A., Iamarino G., Rao M. A., Gianfreda L. 2006. Short-term effects of olive mill waste water (OMW) on chemical and biochemical properties of a semiarid Mediterranean soil. Soil Biology and Biochemistry, 38 (3): 600-610 http://dx.doi.org/10.1016/j.soilbio.2005.06.012

Reddy K. N., Zablotowicz R. M., Locke M. A., Koger C. H. 2003. Cover crop, tillage, and herbicide effects on weeds, soil properties, microbial populations, and soybean yield. Weed Science, 51 (6): 987-994 http://dx.doi.org/10.1614/P2002-169

Richardson A. E., Barea J. M., McNeill A. M., PrigentCombaret C. 2009. Acquisition of phosphorus and nitrogen in the rhizosphere and plant growth promotion by microorganisms. Plant and Soil, 321: 305-339 http://dx.doi.org/10.1007/s11104-009-9895-2

Riddle M. U., Bergstrőm L. 2013. Phosphorus leaching from two soils with catch crops exposed to freeze-thaw cycles. Agronomy Journal, 105 (3): 803-811 http://dx.doi.org/10.2134/agronj2012.0052

Samuel A. D. 2010. Dehydrogenase: an indicator of biological activities in a preluvosoil. Research Journal of Agricultural Science, 42 (3): 306-310
Skinder Z., Wilczewski E. 2004. Forecrop value of nonpapilionaceous plants cultivated in stubble intercrop for spring barley under various fertilization conditions. Electronic Journal of Polish Agricultural Universities, Ser. Agronomy, 7 (1): \#03 <http://www.ejpau.media.pl/ volume 7/issue 1/agronomy/art-03.html $>$

Thalmann A. 1968. Methods of dehydrogenase activity determination with riphenyltetrazoliumchlorid (TTC). Landwirtschaftliche Forschung, 21: 249-258 (in German)

Thorup-Kristensen K., Dresbøll D. B. 2010. Incorporation time of nitrogen catch crops influences the $\mathrm{N}$ effect for the succeeding crop. Soil Use and Management, 26 (1): 27-35 http://dx.doi.org/10.1111/j.1475-2743.2009.00255.x

United Nations. 2006. World population prospects the 2004 revision, vol. III: analytical report. New York, USA

Vaz C. M. P., Manieri J. M., de Maria I. C., Tuller M. 2011. Modeling and correction of soil penetration resistance for varying soil water content. Geoderma, 166 (1): 92-101 http://dx.doi.org/10.1016/j.geoderma.2011.07.016

Vos J., van der Putten P. E. L. 2001. Field observations on nitrogen catch crops. III. Transfer of nitrogen to the succeeding main crop. Plant and Soil, 236 (2): 263-273 http://dx.doi.org/10.1023/A:1012795020139

Wilczewski E., Skinder Z., Szczepanek M. 2012. Effects of weather conditions on yield of tansy phacelia and common sunflower grown as stubble catch crop. Polish Journal of Environmental Studies, 21 (4): 1053-1060

Zablotowicz R. M., Reddy K. N., Krutz L. J., Gordon R. E., Jackson R. E., Price L. D. 2011. Can leguminous cover crops partially replace nitrogen fertilization in Mississippi delta cotton production? International Journal of Agronomy, 2011: 1-9

http://dx.doi.org/10.1155/2011/135097

ISSN 1392-3196 / e-ISSN 2335-8947

Zemdirbyste-Agriculture, vol. 102, No. 1 (2015), p. 23-30

DOI 10.13080/z-a.2015.102.003

\title{
Žirnių kaip tarpinio pasėlio įtaka išplautžemio savybėms ir vasarinių miežių derliui
}

\author{
E. Wilczewski, A. Piotrowska-Długosz, G. Lemańczyk \\ Technologijos ir gyvybės mokslų universitetas, Lenkija
}

\section{Santrauka}

Šiuo metu bendrame auginamų žemès ūkio augalų plote javų dalis yra per didelè, dèl to prastèja dirvožemio savybés ir sunku gauti didelị derlių. Tyrimu siekta nustatyti žirnių kaip tarpinio pasėlio įtaką dirvožemio savybėms ir vasarinių miežių, augintų javų sėjomainoje po tarpinių pasèlių, derlingumui. Buvo tirti šie tarpinio pasèlio naudojimo variantai: A - trapinis pasėlis užartas rudenị, B - tarpinis pasėlis paliktas kaip mulčias žiemai, C kontrolinis variantas (be tarpinio pasėlio). Bandymai vykdyti išplautžemyje (ID) pagal randomizuoto bloko schemą. Užarta tarpinio pasėlio masè žymiai padidino dirvožemio viršutinio sluoksnio drègmès kiekị ir sumažino suslègimą prieš vasarinių miežiu sėją. Žirnių kaip tarpinio pasėlio panaudojimas dirvožemyje padidino fermentų aktyvumą ir mineralinio azoto kiekị prieš sèją bei miežių krūmijimosi metu. Mulčio įtaka buvo ryškesnè palyginus su variantu, kuriame biomasė buvo užarta rudenị. Tarpinis pasẻlis žymiai padidino vasarinių miežių derlingumą labiausiai dèl padidejjusio varpų skaičiaus ir grūdų skaičiaus varpoje miežiuose, augintuose po užarto tarpinio pasèlio, ir dèl padidejjusio grūdų skaičiaus varpoje variantuose su mulčiu. Dirvožemio fizikinès ir biologinès savybės javų sejjomainoje gali smarkiai pagerèti dèl tarpinio pasėlio, ypač panaudoto kaip mulčias.

Reikšminiai žodžiai: dirvožemio mikrobų biomasè, mulčas, sẻjamasis žirnis, vasariniai miežiai, žalioji trąša. 